\title{
Overview of Definitions of Maritime Safety, Safety at Sea, Navigational Safety and Safety in General
}

\author{
K. Formela, T. Neumann \& A. Weintrit \\ Gdynia Maritime University, Gdynia, Poland
}

\begin{abstract}
There are numerous diverse papers that have addressed issues within maritime safety, safety at sea, navigational safety and safety in general; to date there has been no comprehensive review of definitions of these terms. This paper reviewed the definitions on safety in three key areas: maritime safety, safety at sea and navigational safety, and interventions to make navigation and shipping safer. In the paper the authors also deal with issues related to risk analysis and risk management in maritime transport.
\end{abstract}

\section{INTRODUCTION}

The general definition of the term "safety" is usually understood as the condition of being protected from or unlikely to cause danger, risk, or injury [23]. In the other words, safety is a state in which hazards and conditions leading to physical, psychological or material harm are controlled in order to preserve the health and well-being of individuals and the community. It is an essential resource for everyday life, needed by individuals and communities to realise their aspirations [30]. Because of the context, the area it covers and the field in which it occurs there are many different definitions of safety. The concept of safety has evolved over the centuries, and in the last decades of the twentieth century, the importance has changed significantly. Due to changes in marine shipping and the international environment at the turn of the eighties and nineties of the twentieth century, special attention was paid to the perception of maritime and navigational safety. And before we go on to discuss these definitions, let's start with the definition of functional safety and safety in transport in general.

\section{DEFINITION OF SAFETY IN TRANSPORT IN GENERAL}

Functional safety is a concept applicable across all industry sectors. It is fundamental to the enabling of complex technology used for safety-related systems. It provides the assurance that the safety-related systems will offer the necessary risk reduction required to achieve safety for the equipment. But let's start with a definition of safety: Freedom from unacceptable risk of physical injury or of damage to the health of people, either directly, or indirectly as a result of damage to property or to the environment [12].

Functional safety is the part of the overall safety that depends on a system or equipment operating correctly in response to its inputs. Functional safety is the detection of a potentially dangerous condition resulting in the activation of a protective or corrective device or mechanism to prevent hazardous events arising or providing mitigation to reduce the consequence of the hazardous event.

Transport safety can be defined in a number of ways, including the official World Health 
Organisation (WHO) safety definition 'freedom from unacceptable risk of harm'. Road safety is, however, usually defined in a different way. Safe road traffic is characterised by the absence of crashes, injuries and fatalities [35].

For community and for the individual, the loss of health is the most serious effect of crashes. It leads both to serious personal suffering and to huge societal losses in monetary terms. Therefore, it is essential to state at this early stage that loss of health is the main road safety criterion. Convalescence and health restoration have economic consequences as have vehicle damage and loss of vehicles and goods.

Transport safety may be influenced along many separate dimensions and various models have been used in safety management $[4,5]$ :

- there are three main variables that decide the road safety level in terms of health consequences: exposure in traffic, risk of a crash given the exposure, consequence of the crash;

- the health consequences of crashes may be influenced by actions taken before the crash (active safety), during the crash (passive safety), and postcrash (rescue, treatment, rehabilitation);

- most of the crashes are triggered by human errors, sometimes intentional but normally unintentional. There are three basic ways to reduce the human errors: selection of road users (for example, licensing), improving road users (for example, information, education, training, and enforcement), adaptation of road and vehicle engineering solutions to human characteristics and limitations (make it easier to drive, to bicycle, to walk in traffic).

\section{SAFETY AT SEA}

Safety at sea is definitely the first thing seafarer must bear in mind before starting his navigation. It's a known fact that sea can be disarmingly attractive in one moment and already in other it can change its deceptive nature and turn into the biggest nightmare he has ever experienced. Anyone who spent some times at sea has probably felt it on his own skin. Safety is therefore crucial, and the knowledge, experience, skills and safety equipment mandatory part of every sea voyage.

Safety first is the slogan that adorns the deck of majority of merchant ships around the world. With this slogan in mind, the mission of each maritime university, academy and training centre is to permanently promote safety at sea.

These institutions remain a busy and important forum for the wider shipping community and in spite of difficult economic conditions, technological innovation continues to move forward, with obvious implications for safety at sea. One of the most important factors for ensuring safety at sea is effective communication technology, at the forefront of which are modern satellite services.

\section{DEFINITIONS OF MARITIME SAFETY}

Shipping is perhaps the most international of all the world's great industries - and one of the most dangerous. It has always been recognized that the best way of improving safety at sea is by developing international regulations that are followed by all shipping nations.

IMO's first task when it came into being in 1959 was to adopt a new version of the International Convention for the Safety of Life at Sea (SOLAS) [32], the most important of all treaties dealing with maritime safety. IMO has also developed and adopted international collision regulations and global standards for seafarers, as well as international conventions and codes relating to search and rescue, the facilitation of international maritime traffic, load lines, the carriage of dangerous goods and tonnage measurement. Navigation regulations such as the official regulations of the International Maritime Organization (IMO) are an essential instrument for safety in navigation [19]. The Maritime Safety Committee is IMO's senior technical body on safetyrelated matters. It is aided in its work by a number of Sub-Committees:

- Carriage of Cargoes and Containers (CCC),

- Human Element, Training and Watchkeeping (HTW),

- Implementation of IMO Instruments (III),

- Navigation, Radio-communication and Search \& Rescue (NCSR),

- Pollution Prevention and Response (PPR),

- Ship Design and Construction (SDC),

- Ship Systems \& Equipment (SSE).

The basic legal act regulating the safety of navigation in Poland is the Act of 18 August 2011 on maritime safety [28]. Under this Act, the safety of navigation is provided on many levels by:

- inspection of technical condition and safety management on ships of Polish affiliation,

- safe manning of ships,

- control of foreign ships calling at Polish ports,

- certification and control of marine equipment,

- monitoring of vessel traffic,

- provision of navigational marking, hydro meteorological protection and

- communications at sea.

Maritime safety is defined as the safety of life, health and property against environmental and operational risks associated with navigation [28]. Because it is a broad concept and its formulation depends on the context and the individual approach, universal definitions of maritime safety can include the following [3]:

- freedom from danger,

- no risk, the level of which cannot be accepted, or the lack of harm to human health (freedom from unacceptable risk or personal harm),

- no financial losses.

Safety can be defined as the state of the marine system (ship, person, surroundings) in which none of its elements for any given reason threatens any other element of the system.) In navigation, the state of danger is caused by a maritime accident, understood as an undesirable event causing significant damage 
and loss (material and personal) as a result of collision or internally contradictory interactions in the system: man-object-surroundings [7]. It must be mentioned that of the components constituting maritime safety the most variable is navigational safety. For this reason maritime safety assessment of an individual ship usually comes down to assessing her navigational safety [17].

Maritime safety is sometimes defined also as "such desirable conditions of human activity at sea that do not endanger human life and property, and are not harmful to the marine environment". It is composed of four components namely technological and operational ships' safety, safety of navigation, safety of person in distress, and prevention of pollution of environment from ships as shown in Figure 1 [18].

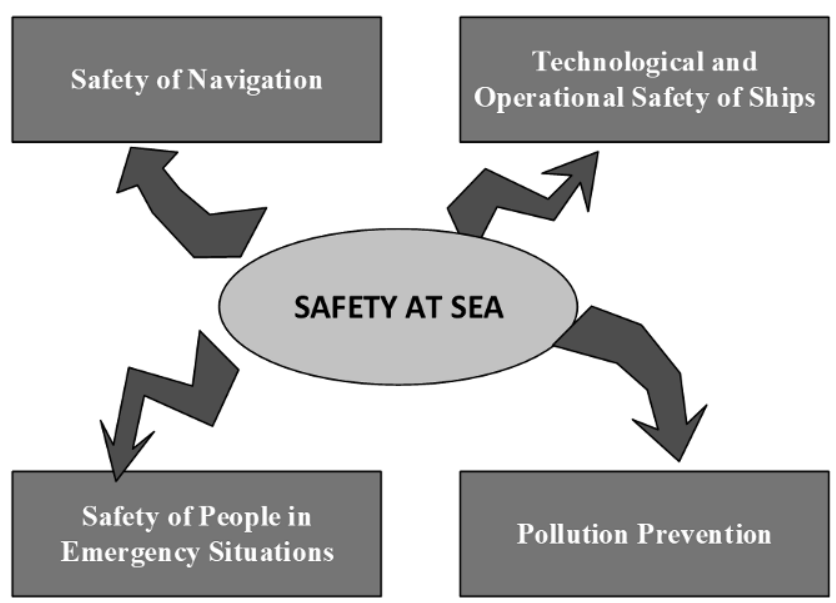

Figure 1. Four major components of safety at sea [18]

\section{DEFINITIONS OF NAVIGATIONAL SAFETY}

Navigation is a basic element of a complex safety system at sea, related to the human factor. Impact, both the elements of the system as well as the navigation process itself have such factors as [15]:

- type, purpose and tasks of the ship,

- ship's naval characteristics, manoeuvrability and technical data,

- environmental conditions of the reservoir in which the ship is operated,

- number of deposit members and their qualifications.

There are many factors influencing the level of navigation safety, among which three systems can be distinguished [16]:

- bridge manning (navigation processes),

- marine environment (disturbance level),

- technical and legal aspects related to the navigation process.

Maritime navigation is seen as a complex of activities including science, knowledge and practice, enabling relocating vessels in water areas between specified points, providing them with an appropriate level of safety for the assumed criteria and limitations. Knowledge about safe and efficient navigation in the seas and oceans basically includes its methods. Research and the development of new techniques are constantly implemented in the navigation practice [15]. The safety status of marine navigation can be presented as a function depending on many technical parameters of ships, the state of the environment and infrastructure of the swimming area and the level of qualifications of navigators [15], [18]:

$$
B_{N}=f\left(P_{N}, W_{N}, M_{S}, I_{R}, S_{i}, N_{S}, K_{Z}, S_{A}, S_{P}, Z_{N}, G_{S}\right)
$$

where:

$P_{N}$ - level of conducting navigational processes,

$W_{N}$ - the state of ship's equipment,

Ms - parameters of ship's manoeuvring

characteristics,

$I_{R}$ - level of navigation infrastructure,

$S_{i} \quad$ - type of information system about the marine environment,

Ns - level of navigational information services,

$\mathrm{Kz}$ - competences and qualifications of the ship's crew,

$\mathrm{S}_{\mathrm{A}}$ - the ability of ships to call on the signals of calling for help,

Sp - ability to assist,

$Z_{N}$ - the ability to help ships in distress,

Gs- - the state of the geographical environment.

Navigational safety is therefore one of the priority tasks for today's shipping. It consists in carrying a vessel from the point of departure to the point of destination without threats to human health and life, economic losses and threats to the environment. Navigational safety assessments can be done using an $P_{i}$ indicator calculated on the basis of these factors [34]:

$$
P_{i}=f\left(A_{i}, S_{i}, N_{i}, H_{i}, M_{i}, I_{i}, R_{i}, F_{i}\right)
$$

where:

$P_{i} \quad$ - navigation safety assessment indicator,

$\mathrm{A}_{\mathrm{i}}$ - sea area parameters,

$S_{i} \quad$ - ship's parameters,

$\mathrm{N}_{\mathrm{i}}$ - parameters of positioning systems,

$\mathrm{H}_{\mathrm{i}}$ - hydro meteorological parameters,

$\mathrm{M}_{\mathrm{i}}$ - parameters of the manoeuvre,

$\mathrm{I}_{\mathrm{i}}$ - parameters of traffic density,

$\mathrm{R}_{\mathrm{i}}$ - parameters of the traffic control system,

$F_{i}$ - human factor.

The Pi shipping safety indicator can be expressed using the probability of accident (failure) indicator $P_{A}$ [34]:

$P_{i}=\left(1-P_{A}\right)$

Manoeuvring a vessel navigating in the sea is associated with the risk of an accident. The vessel's navigational safety is determined by an acceptable risk that can be described as [34]:

$$
R_{a c c}=P_{A} \cdot C_{\min }
$$

where:

Racc - acceptable risk,

$P_{A}$ - accident (failure) indicator,

$C_{\min }$ - acceptable level of losses. 
In the view of marine traffic engineering, the construction of a navigational risk model on marine waterways requires the determination of basic parameters of the navigation safety assessment, such as [8]:

- width of the safe manoeuvring area,

- navigational reliability of the vessel on the waterway,

- technical reliability of the ship,

- kinetic energy of hitting the ship on the berth,

- kinetic energy of contact between the ship and the bottom of the sea,

- kinetic energy of the collision of two ships.

The human factor is very important but difficult to take into account in assessing navigational safety [24]. The Nautical Institute has investigated the causes of collisions and groundings over the past 10 years, in which human error was the primary cause. Collisions and groundings due to mechanical and structural failures were not taken into account, nor were incidents where vessels dragged anchor, collided with quays and jetties or were under control of tugs. These constituted about 40 per cent of all incidents of collision and grounding, leaving 60 per cent of incidents accounted for by direct human error [6]. The human factor consists fatigue, automation, situation awareness, communication, decision making process, team work, health and stress. These individual factors can be contributory causes in accident causation, however the safety climate on ship will also influence whether or not an individual engages in safe behaviors or not [9]. It is important to mention, that the quantitative assessment of navigational safety, as well as other types, can be carried out by estimating the reliability of the system. The degree of risk can be regulated by intentional actions aimed at finding the optimal decision [20].

Navigation safety is defined as a relatively constant state, clear of dangers provided by the system of international and national technical, organizational, economic, social, and juridical standards, which are aimed at the reduction and prevention of accidents at sea to provide safety of life and property at sea and marine environmental protection [33].

Another definition presents navigation safety as a component of the maritime safety, which includes, apart from navigational hazards, other aspects like stability, fire or cargo hazards. Maritime safety together with the safety of the marine environment is part of the concept of safety at sea, defined as the state of human activity at sea causing threats to ships, human life and the environment [7].

Navigation safety assessment can be carried out using the probabilistic method. This method enables determine probability by using methods of fault tree and event tree analyses.

On this basis it is possible to estimate the navigational risk and examine ways of counteracting and reducing risks in vessel traffic - risk management in sea transport, which is of major importance for the assurance of safe navigation [25].
6 RISK ANALYSIS AND RISK MANAGEMENT IN MARITIME TRANSPORT

Presented recommendations and regulations in the field of safety management in water transport are related to maritime transport. They cover various levels (international, regional, national or industry) of management and organization responsible for maritime safety management systems, which have to be maintained as a continuous cycle [26, 29]. Risk assessment is therefore recurrent.
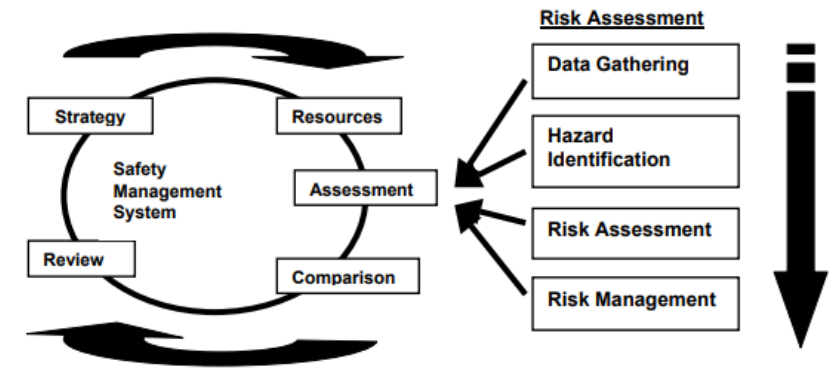

Figure 2. Relationship between Risk Assessment and the Safety Management System [29]

All these standards for risk management provides base information to set a common standard for assessments undertaken (risk assessment defines the risks and a safety management system manages the risks). The risk assessment has to start with identification of hazards (as something with the potential to cause harm to people, environment or property). Once a hazard is identified, frequency and consequence data must be added. Risk is a combination of the frequency (likelihood, probability or chance) of a hazard realization and the consequence (severity or impact) of the hazard reaching its potential [29]. The risk assessment can be undertaken by qualitative or quantitative approach.

The main document on risk management in maritime transport is the methodology of a formalized safety management procedure (FSA Formal Safety Assessment) issued by International Maritime Organization (IMO), based on the generally accepted risk management methodology $[13,26]$. FSA is a structured and systematic methodology, aimed at enhancing maritime safety, including protection of life, health, the marine environment and property, by using risk analysis and cost benefit assessment. A five-level risk management procedure based on the FSA methodology recommended by the IMO includes [13]:

1 identification of hazards (a list of all relevant accident scenarios with potential causes and outcomes),

2 assessment of risks (evaluation of risk factors),

3 risk control options (devising regulatory measures to control and reduce the identified risks),

4 cost benefit assessment (determining cost effectiveness of each risk control option),

5 recommendations for decision-making (information about the hazards, their associated risks and the cost effectiveness of alternative risk control options is provided). 


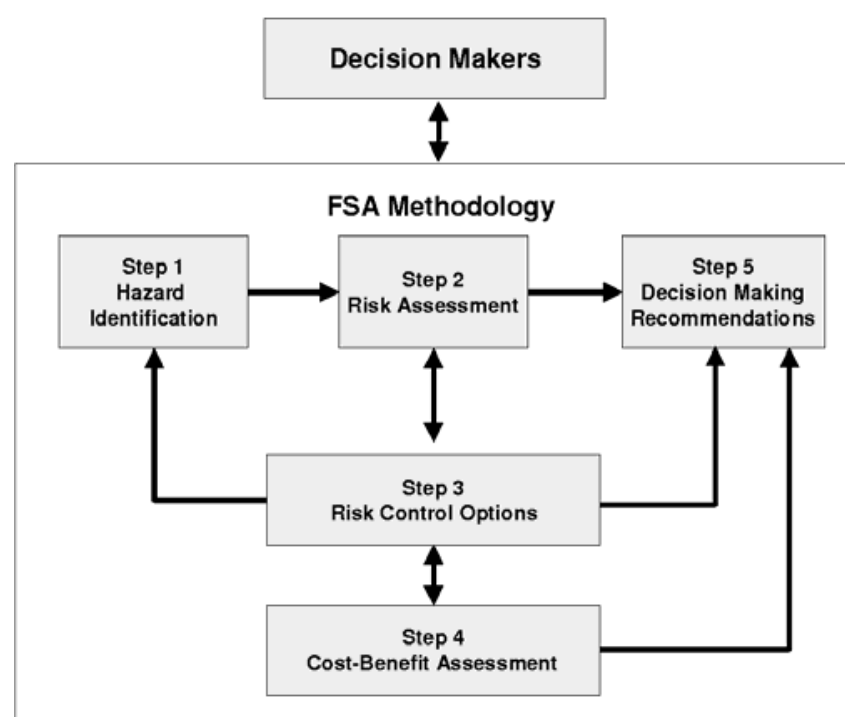

Figure 3. The FSA Process [13]

Another document which sets out an international standard for the safe management and operation of ships and the prevention of pollution is International Ship Safety Management Code (ISM) introduced into the International Convention for the Safety of Life at Sea (SOLAS) [6]. The application of the ISM Code should support and motivate the development of safety culture in shipping. The purpose of the ISM Code is to ensure safety at sea, to prevent accidents or loss of life and to avoid damage to the marine environment and property $[14,26]$.

Other documents are recommendations issued by national, regional (for example, EMSA) and international agencies and organizations. An example is International Association of Marine Aids to Navigation and Lighthouse Authorities (IALA), which provides its members with two risk management tools: IWRAP (IALA Waterways Risk Assessment Program) and PAWSA (Port and Waterways Assessment) [10]. IWRAP is a modelling tool useful for maritime risk assessment. Using IWRAP it is possible to estimate the frequency of collisions and groundings in a given waterway based on information about traffic volume/composition and route geometry [11]. PAWSA provides an assessment of risk in a defined waterway and the output indicates whether the existing risk in a waterway is [10]:

- acceptable and that no further work is needed unless changes occur in significant criteria, such as the traffic pattern or types of vessels using that waterway,

- not acceptable but the risk control options necessary to make the risk level of the waterway acceptable have been identified adequately,

- not acceptable and more detailed study is necessary to enable the risk control options that will make the risk level of the waterway acceptable to be identified adequately.

Another very active association in the field of maritime safety is World Association for Waterborne Transport Infrastructure PIANC (its earlier name was as the Permanent International Association of Navigation Congresses PIANC; it is additionally known as the International Navigation Association) with its technical commissions and working groups of experts.

Recommended Practice for Risk management in marine issued by Classification Society Det Norske Veritas (DNV) is an example of industry standards [31]. The overall objective with this Recommended Practice is to establish guidelines and recommendations for the process required to reach an acceptable and controlled exposure to risk during marine operations, for personnel, environment, assets and reputation [31]. British Ports (UK Port Marine Safety Code [21]), New Zealand (Port \& Harbor Risk Assessment and Safety Management System [29]) and Canadian (Pilotage Risk Management Methodology [27]) are good examples of domestic norms for risk estimation in seaports [25]. It's also common, that countries are taking activities aimed at improving safety at sea on their own. In view of the forecasted increase in traffic volume [1], [22] related to Arctic oil and gas production, export of ores and other minerals and possible commercial use of the Northern Sea Route, the Norwegian authorities have identified a need for greater efforts to raise the level of safety for shipping in Norwegian waters, particularly in the north [2]. Such examples can be multiplied here.

\section{CONCLUSIONS}

Transport safety can be defined in a number of ways. This article presents definitions of maritime safety, safety at sea, navigational safety and safety in general. It looks at the development of responses to a number of aspects of safety at sea, and draws lessons for the future. In the past, many safety issues for shipping have been addressed by legislation. And it seems like it's a good way.

The review of matters related to maritime safety should include studies of shipping across the following areas: seafarer's fatigue, stress, health, situation awareness, teamwork, decision-making, communication, exchange of information, technological development, digitalization, automation, and above all safety culture.

\section{REFERENCES}

[1] Arctic Council, 2009: Arctic Marine Shipping Assessment - 2009 Report, PAME, Borgir, Nordurslod - 600 Akureyri, Iceland, 2009.

[2] Berg, T.E., Kvamstad, B., Kjersem, F. (2011). Safety at Sea - a Review of Norwegian Activities. TransNav, the International Journal on Marine Navigation and Safety of Sea Transportation, Vol. 5, No. 2, pp. 195-201.

[3] Burciu Z., Safety in Maritime Transport and Management in the Rescue Operation (in Polish): Bezpieczeństwo $\mathrm{w}$ transporcie morskim i zarządzanie $\mathrm{w}$ akcji ratowniczej. Wydawnictwo Akademii Morskiej w Gdyni, Gdynia 2011. ISBN: 978-83-7421-161-1.

[4] ETSC: Intelligent Transportation Systems and Road Safety. European Transport Safety Council 1999 [electronic source]. Accessible on: www.etsc.eu/oldsite/systems.pdf

[5] ETSC Strategic Road Safety Plan for the European Union, European Commission 1997. 
[6] Gale, H., Patraiko, D. (2007). Improving navigational safety. Seaways, July 2007.

[7] Gucma S. (ed.) Maritime Ferry Terminals - Design and Operation in Terms of Marine Traffic Engineering): Morskie terminale promowe - projektowanie i eksploatacja w ujęciu inżynierii ruchu morskiego. Monografia pod redakcją Stanisława Gucmy.

[8] Gucma S. (ed.). Sea Waterways - Design and Operation in Terms of Marine Traffic Engineering (in Polish): Morskie drogi wodne - projektowanie i eksploatacja w ujęciu inżynierii ruchu morskiego. Wydawnictwo: Fundacja Promocji Przemysłu Okrętowego i Gospodarki Morskiej, Gdańsk 2015. ISBN 978-83-60584-51-4.

[9] Hetherington, C., Flin, R., Mearns, K., Safety in Shipping: The human element, Journal of Safety Research, 2006, v.37, 401-411.

[10] IALA Guideline - G1124. The use of Ports and Waterways Safety Assessment (PAWSA) MK II TOOL. International Association of Marine Aids to Navigation and Lighthouse Authorities, St Germain en Laye, France, June 2017.

[11] IALA Training Seminar on Risk Management PAWSA, IWRAP MK2 \& Simulation. Final Report. International Association of Marine Aids to Navigation and Lighthouse Authorities, St Germain en Laye, France, 15-19 November 2010.

[12] IEC 61508-1:2010. Functional safety of electrical/electronic/programmable electronic safetyrelated systems - Part 1: General requirements. Edition 2. International Electrotechnical Commission, Genève, 2010.

[13] IMO MSC-MEPC.2/Circ.12/Rev.2. Revised Guidelines for Formal Safety Assessment (FSA) for use in the IMO Rule Making Process. International Maritime Organization, London, 9 April 2018.

[14] ISM Code and Guidelines on Implementation of the ISM Code. International Maritime Organization, London, 2015.

[15] Jurdziński M., Basics in Marine Navigation (in Polish): Podstawy nawigacji morskiej. Wydawnictwo Akademii Morskiej w Gdyni, Gdynia 2003. ISBN 83-87438-58-8

[16] Jurdziński M., Navigation Planning in Restricted Areas (in Polish): Planowanie nawigacji w obszarach ograniczonych, Fundacja Rozwoju Wyższej Szkoły Morskiej, Gdynia 1999.

[17] Kopacz Z., Morgaś W., Criteria for estimating navigational safety at sea. Scientific Journal of Polish Naval Academy, Gdynia 2015.

[18] Kopacz Z., Morgaś W., Urbański J., The Maritime Navigation its Environment and its Safety System, Annual of Navigation, No 4/2002.

[19] Kreutzmann A., Wolter D., Dylla F., Lee J.H., Towards Safe Navigation by Formalizing Navigation Rules. TransNav, the International Journal on Marine Navigation and Safety of Sea Transportation, Vol. 7, No. 2, doi:10.12716/1001.07.02.01, pp. 161-168, 2013

[20] Łusznikow M., Ferlas Z., Safety of Navigation (in Polish): Bezpieczeństwo żeglugi. Wydawnictwo Wyższej Szkoły Morskiej w Szczecinie, Szczecin 1999. ISBN 8386494-47-6.
[21] MCA Port Marine Safety Code. Maritime \& Coastguard Agency. Department for Transport. November 2016.

[22] Norwegian Ministry of the Environment, 2006: A holistic management plan for the marine environment in the Barents Sea and waters outside Lofoten, Governmental White Paper no. 8 (2005-2006), Oslo, Norway.

[23] Oxford Dictionary of English (3 ed.). Oxford University Press, 2010. ISBN: 9780199571123.

[24] Patraiko D., Wake P., Weintrit A., e-Navigation and the Human Element. TransNav, the International Journal on Marine Navigation and Safety of Sea Transportation, Vol. 4, No. 1, 2010

[25] Pietrzykowski Z., Assessment of Navigational Safety in Vessel Traffic in an Open Area. TransNav, the International Journal on Marine Navigation and Safety of Sea Transportation, Vol. 1, No. 1, 2007.

[26] Pietrzykowski Z., Automation of Collision Avoidance Processes (in Polish): Automatyzacja procesów zapobiegania kolizjom na morzu. Wydawnictwo naukowe Akademii Morskiej w Szczecinie, Szczecin 2017. ISBN 978-83-64434-18-1.

[27] Pilotage Risk Management Methodology (PRMM). Her Majesty the Queen in Right of Canada, as represented by the Minister of Transport, 2001. Printed in Canada. ISBN: 978-1-100-15102-1.

[28] Polish Act on Maritime Safety (in Polish): Ustawa z dnia 18 sierpnia 2011 r. o bezpieczeństwie morskim. Dz. U. 2011 Nr 228 poz. 1368.

[29] Port \& Harbour Risk Assessment and Safety Management Systems in New Zealand. Maritime Safety Authority of New Zealand, New Zealand 2004.

[30] Québec WHO Collaborating Centre for Safety Promotion and Injury Prevention, WHO Collaborating Centre on Community Safety Promotion, Karolinska Institutet, World Health Organisation, 1998. Safety and Safety Promotion: Conceptual and Operational Aspects, Québec.

[31] Risk Management in Marine - and Subsea Operations. Recommended Practice No. DNV-RP-H101. Det Norske Veritas. January 2003

[32] SOLAS, Safety of Life Convention, Consolidated Edition 2014. International Maritime Organization; London, September 18, 2014. ISBN-10: 9280115944

[33] Torskiy, V., Topalov, V.P., Chesnokova, M.V. (2016). Conceptual Grounds of Navigation Safety. TransNav, the International Journal on Marine Navigation and Safety of Sea Transportation, Vol. 10, No. 1, doi:10.12716/1001.10.01.08, pp. 79-82.

[34] Weintrit A. (ed.), Navigational and Hydrographic Aspects of Sea-River Navigation in Poland (in Polish): Nawigacyjno-hydrograficzne aspekty żeglugi morskorzecznej w Polsce. Wydawnictwo Akademii Morskiej w Gdyni, Gdynia 2010. ISBN 978-83-7421-138-3.

[35] Weintrit, A., Neumann, T. (eds), Safety of Marine Transport, Marine Navigation and Safety of Sea Transportation, CRC Press-Taylor \& Francis Group, Boca Raton - London - New York - Leiden 2015 